\title{
Natural and Anthropogenic Conditions of the Chemical Composition of Pit Lake Waters (Based on Example Pit Lakes from Central Europe)
}

\author{
Tadeusz Molenda $^{1}$ (D) Joanna Kidawa ${ }^{1}$ (D)
}

Received: 4 January 2019 / Accepted: 22 January 2020 / Published online: 31 January 2020

(c) The Author(s) 2020

\begin{abstract}
The article presents a classification of hydrochemical types of waters in pit lakes. Although natural factors significantly influence the chemical composition of water, the differences between hydrochemical types are also determined by anthropogenic factors. The chemical composition of the water in pit lakes is primarily determined by the kind of rocks mined during the excavation, while secondary anthropogenic impacts can modify the chemical composition of the water. A multidimensional clustering analysis of the water was performed, which allowed three main types of hydrochemical reservoirs to be delimited for the pit lakes assessed in this study: a bicarbonate-magnesium-calcium water type $\left(\mathrm{HCO}_{3}-\mathrm{Mg}-\mathrm{Ca}\right)$, a bicarbonate-calcium water type $\left(\mathrm{HCO}_{3}-\mathrm{Ca}\right)$, and a sulphate-calcium water type $\left(\mathrm{SO}_{4}-\mathrm{Ca}\right)$.
\end{abstract}

Keywords Mining water $\cdot$ Hydrochemical type of water $\cdot$ Water pollution $\cdot$ Industrial waste $\cdot$ Mineral resources

\section{Introduction}

Anthropogenic water bodies are a new element in the natural environment (Jankowski 1995). These water bodies are divided into various types, depending on the origin of the basin and include pit lakes that have formed due to the flooding of excavations that were once used for the opencast exploitation of mineral resources (Fig. 1). Although these pit lakes do not have a natural origin, they are subject to the same processes as natural lakes. These effects include the chemical composition of the water. Studies on the chemical properties of the water in pit lakes have included numerous objects (Castendyk et al. 2015a, b; Eary 1999; Jones et al. 2003; Rzętała 2008; Schultze et al. 2013). However, they have primarily concerned individual water bodies. Hydrochemical analyses have also been limited to a few selected ions (Boehrer et al. 2017; Malata et al. 2018; Molenda 2014, 2015, 2018; Sánchez-España et al. 2014; Schultze et al. $2017 \mathrm{a}, \mathrm{b})$. Studies of their more general characteristics that were based on the hydrochemical type of the retained waters

Joanna Kidawa

joanna.kidawa@us.edu.pl

Tadeusz Molenda

tadeusz.molenda@us.edu.pl

1 Faculty of Earth Sciences, University of Silesia, Katowice, Poland have been carried out for natural lakes (Hammer 1986; Hutchinson 1975; Rahaingomanana 1998).

This article demonstrates how the properties of the catchment (natural and anthropogenic) affect the chemical composition of the water in post-exploitation pit lakes. A classification of the pit lakes investigated in this study is also presented relative to the hydrochemical water type.

\section{Study Sites}

Thirty pit lakes in the Republic of Poland and the Czech Republic were selected for this research. The detailed locations of the pit lakes are presented in Table 1 and Fig. 2. The pit lakes differed regarding the type of minerals that had been extracted, which ranged from energy resources to construction (Table 1). The stages of pit lakes that were formed are presented Fig. 1. All of the tested pit lakes are endorheic. They are supplied only by groundwater inflow, rainfall, and surface runoff from their direct catchments. The surface area of the tested pit lakes is diverse and ranges from $3000 \mathrm{~m}^{2}$ to several ha.

\section{Research Methods}

Water samples were collected in spring and autumn in $0.5 \mathrm{~L}$ polyethylene bottles and then transported to the laboratory at 
1

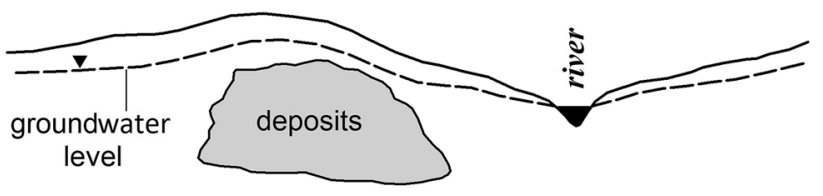

2

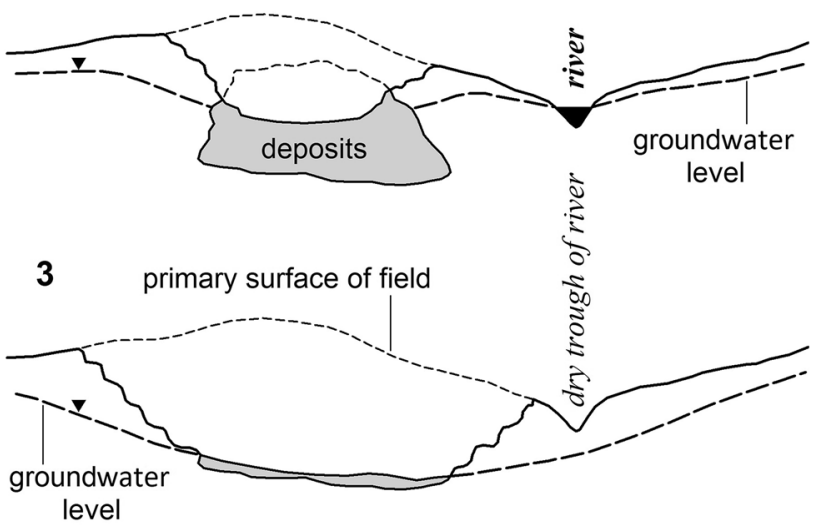

4

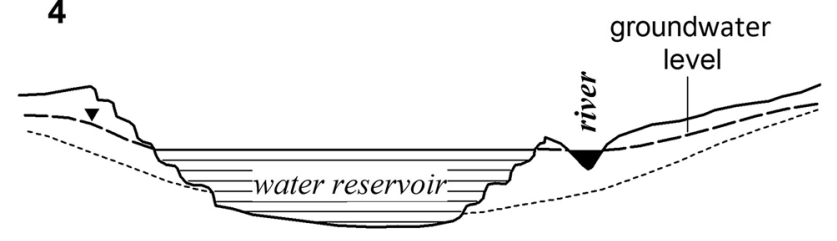

Fig. 1 Stages of excavation reservoir forming according to Molenda and Chmura (2011)

$+4{ }^{\circ} \mathrm{C}$ for analysis. The aim of this sampling was to obtain homogeneous samples of the mixed water of each pit lake (Schultze et al. 2017a, b). These pit lakes are located in mid latitudes, which have four seasons (Tables 1, 2, and 3). In both spring and autumn, the water temperature in the tested pit lakes falls below $4{ }^{\circ} \mathrm{C}$ and the water circulates completely (Imberger and Patterson 1990). During this period, there were no differences in the concentrations of individual ions in the water column of these pit lakes (Malata et al. 2018; Molenda and Chmura 2011). Therefore, a surface water sample is representative of the entire water body. Six samples were taken from each pit lake from 2015 to 2017 (three in spring and three in autumn; $n=6$ ).

Before analysis, the samples were filtered $(0.45 \mu \mathrm{m}$ Millipore). The major cations and anions in the water: $\mathrm{Ca}^{2+}, \mathrm{Mg}^{2+}, \mathrm{Na}^{+}, \mathrm{K}^{+}, \mathrm{SO}_{4}{ }^{2-}, \mathrm{Cl}^{-}$were determined using a Metrohm 850 Professional IC ion chromatograph (anion column A Suup 7-250/4.0, eluent $3.6 \mathrm{mM} \mathrm{Na}_{2} \mathrm{CO}_{3}$ and a cation column C4-150/4, eluent $0.7 \mathrm{mM}$ dipicolinic acid and $1.7 \mathrm{HNO}_{3}$ ).

Classification of the hydrochemical type of the water retained in the pit lake was based on the Altowski-Szwiec classification (Pazdro and Kozerski 1990). This method determines the hydrochemical type by the ions whose content in the water is greater than $20 \pm 3 \%$ equivalents (meq), provided that the sum of anions and cations equals $100 \%$. The name of the water type begins with the ion whose content is the highest in the water, regardless of whether it is a cation or an anion. If the name of three- or four-ion water starts with an anion, then the following elements of the name are other anions followed by cations in the same order. In natural conditions, the six most critical ions of over $20 \%$ meq are $\mathrm{Ca}^{2+}, \mathrm{Mg}^{2+}, \mathrm{Na}^{+}, \mathrm{HCO}_{3}{ }^{-}, \mathrm{Cl}^{-}, \mathrm{SO}_{4}{ }^{2-}$. For this reason, these ions were selected for analysis. Potassium $\left(\mathrm{K}^{+}\right)$ was also included.

In addition to the chemical analyses of water, an analysis of the mineral composition of the industrial waste that had been deposited in the shore zone of some of the pit lakes was also carried out. The mineral composition of the industrial waste was determined using: a phase X-ray diffractometer (XRD) Philips PW 3710 with a graphite monochromator, and sub-microscopic tests (scanning microscope Philips XL 30, analytical EDS, EDAX, sapphire type).

To examine the similarities and differences between the individual pit lakes, a multivariate analysis andcluster analysis was used in which the Euclidean distance was used as a measure of similarity and the Ward method of grouping was adopted. The average concentration $(\mathrm{meg} / \mathrm{L})$ of the basic ions in the water of the tested pit lakes was assumed to be its features. The statistical analysis was performed using R ( R Development Core Team 2009) software.

\section{Results and Discussion}

The multidimensional clustering analysis delimited three main groups of pit lakes that differed in the chemical composition of their waters (Fig. 3). The most specific group included pit lakes 1 and 2, which were of a chloride-sodium $\left(\mathrm{Cl}-\mathrm{Na}^{+}\right)$water type. These pit lakes are located in the postexploitation excavations of construction resources, i.e. sands and tills. Usually one would expect these waters to represent a bicarbonate-calcium type $\left(\mathrm{HCO}_{3}{ }^{-}-\mathrm{Ca}^{2+}\right)$, like the waters of the other pit lakes located in this type of excavation (24-27, Table 1). Studies by other authors have also documented a bicarbonate-calcium type $\left(\mathrm{HCO}_{3}{ }^{-}-\mathrm{Ca}^{2+}\right)$ type of the water in pit lakes located in disused sand and till pits (Molenda 2007). This $\mathrm{Cl}-\mathrm{Na}^{+}$type of water is due to an anthropogenic factor: strongly saline waters from hard coal mines had been discharged into the pit lakes. These waters had a high salinity $>3 \mathrm{~g} / \mathrm{L}$ and chloride and sodium ions were dominant. The discharge of these waters into the pit lakes completely transformed the natural hydrochemical type of the water. In the case of pit lake 2, it also resulted 
Table 1 General characteristics of reservoirs

\begin{tabular}{|c|c|c|c|c|c|c|c|c|c|}
\hline Location & $\begin{array}{l}\text { Extracted } \\
\text { material }\end{array}$ & $\begin{array}{l}\mathrm{Ca}^{2+} \\
{[\mathrm{meq} / \mathrm{L}]}\end{array}$ & $\begin{array}{l}\mathrm{Mg}^{2+} \\
{[\mathrm{meq} / \mathrm{L}]}\end{array}$ & $\begin{array}{l}\mathrm{Na}^{+} \\
{[\mathrm{meq} / \mathrm{L}]}\end{array}$ & $\mathrm{K}^{+}[\mathrm{meq} / \mathrm{L}]$ & $\mathrm{Cl}^{-}[\mathrm{meq} / \mathrm{L}]$ & $\begin{array}{l}\mathrm{SO}_{4}{ }^{2-} \\
{[\mathrm{meq} / \mathrm{L}]}\end{array}$ & $\begin{array}{l}\mathrm{HCO}_{3}^{-} \\
{[\mathrm{meq} / \mathrm{L}]}\end{array}$ & $\begin{array}{l}\text { Hydrochemi- } \\
\text { cal type }\end{array}$ \\
\hline $\begin{array}{l}\text { N: } 50^{\circ} 15^{\prime} 40^{\prime \prime} \\
\text { E: } \\
19^{\circ} 7^{\prime} 30^{\prime \prime}\end{array}$ & Sand & 18 & 16.8 & 98 & 1.1 & 147 & 8.5 & 5.2 & $\mathrm{Cl}-\mathrm{Na}$ \\
\hline $\begin{array}{l}\text { N: } 50^{\circ} 14^{\prime} 24^{\prime \prime} \\
\text { E: } \\
18^{\circ} 59^{\prime} 34^{\prime \prime}\end{array}$ & Clay & 9.7 & 6.2 & 57 & 0.8 & 75 & 6.9 & 1.8 & $\mathrm{Cl}-\mathrm{Na}$ \\
\hline $\begin{array}{l}\text { N: } 50^{\circ} 4^{\prime} 36^{\prime \prime} \\
\text { E: } \\
18^{\circ} 24^{\prime} 36^{\prime \prime}\end{array}$ & Gypsum & 26.8 & 0.4 & 0.9 & 0.4 & 1.4 & 22 & 4.7 & $\mathrm{SO}_{4}-\mathrm{Ca}$ \\
\hline $\begin{array}{l}\text { N: } 49^{\circ} 95^{\prime} 51^{\prime \prime} \\
\text { E: } \\
17^{\circ} 89^{\prime} 45^{\prime \prime}\end{array}$ & Gypsum & 27.4 & 2.9 & 1.1 & 0.22 & 1.8 & 21.7 & 2.2 & $\mathrm{SO}_{4}-\mathrm{Ca}$ \\
\hline $\begin{array}{l}\text { N: } 50^{\circ} 27^{\prime} 37^{\prime \prime} \\
\text { E: } \\
20^{\circ} 35^{\prime} 28^{\prime \prime}\end{array}$ & Gypsum & 33 & 3.3 & 1 & 0.26 & 1.3 & 32 & 1.9 & $\mathrm{SO}_{4}-\mathrm{Ca}$ \\
\hline $\begin{array}{l}\text { N: } 50^{\circ} 27^{\prime} 19^{\prime \prime} \\
\text { E: } \\
20^{\circ} 35^{\prime} 9^{\prime \prime}\end{array}$ & Gypsum & 32 & 3.3 & 0.9 & 0.26 & 2.1 & 32.5 & 2.2 & $\mathrm{SO}_{4}-\mathrm{Ca}$ \\
\hline $\begin{array}{l}\text { N: } 50^{\circ} 17^{\prime} 8^{\prime \prime} \\
\text { E: } \\
19^{\circ} 16^{\prime} 39^{\prime \prime}\end{array}$ & Sand & 2 & 0.8 & 0.08 & 0.08 & 0.16 & 2.4 & 0 & $\mathrm{SO}_{4}-\mathrm{Ca}^{\mathrm{a}}$ \\
\hline $\begin{array}{l}\mathrm{N}: 50^{\circ} 30^{\prime} 48^{\prime \prime} \\
\mathrm{E}: \\
18^{\circ} 59^{\prime} 21^{\prime \prime}\end{array}$ & Dolomite & 2.6 & 1.3 & 0.05 & 0.06 & 0.07 & 3.7 & 0 & $\mathrm{SO}_{4}-\mathrm{Ca}^{\mathrm{a}}$ \\
\hline $\begin{array}{l}\text { N: } 50^{\circ} 27^{\prime} 21^{\prime \prime} \\
\text { E: } \\
19^{\circ} 24^{\prime} 46^{\prime \prime}\end{array}$ & Lignite & 2.7 & 0.6 & 0.1 & 0.08 & 0.2 & 3.7 & 0 & $\mathrm{SO}_{4}-\mathrm{Ca}$ \\
\hline $\begin{array}{l}\text { N: } 50^{\circ} 27^{\prime} 5^{\prime \prime} \\
\text { E: } \\
19^{\circ} 23^{\prime} 19^{\prime \prime}\end{array}$ & Lignite & 2.7 & 0.67 & 0.1 & 0.12 & 0.15 & 3.4 & 0.0 & $\mathrm{SO}_{4}-\mathrm{Ca}$ \\
\hline $\begin{array}{l}\text { N: } 50^{\circ} 56^{\prime} 3^{\prime \prime} \\
\text { E: } \\
20^{\circ} 40^{\prime} 51^{\prime \prime}\end{array}$ & Quartzite & 4.6 & 0.95 & 0.17 & 0.08 & 0.15 & 13.7 & 0.00 & $\mathrm{SO}_{4}-\mathrm{Ca}$ \\
\hline $\begin{array}{l}\mathrm{N}: 49^{\circ} 43^{\prime} 50^{\prime \prime} \\
\mathrm{E}: \\
18^{\circ} 44^{\prime} 10^{\prime \prime}\end{array}$ & Limestone & 4.2 & 0.2 & 0.05 & 0.06 & 0.09 & 0.96 & 3.5 & $\mathrm{Ca}\left(\mathrm{HCO}_{3}\right)_{2}$ \\
\hline $\begin{array}{l}\mathrm{N}: 50^{\circ} 13^{\prime} 42^{\prime \prime} \\
\mathrm{E}: \\
19^{\circ} 18^{\prime} 40^{\prime \prime}\end{array}$ & Dolomite & 3 & 3.48 & 0.57 & 0.12 & 0.84 & 1.93 & 3.58 & $\begin{array}{l}\mathrm{HCO}_{3}-\mathrm{Mg}- \\
\mathrm{Ca}\end{array}$ \\
\hline $\begin{array}{l}\text { N: } 50^{\circ} 13^{\prime} 30^{\prime \prime} \\
\text { E: } \\
19^{\circ} 19^{\prime} 1^{\prime \prime}\end{array}$ & Dolomite & 3.34 & 3.5 & 0.64 & 0.14 & 0.97 & 2.14 & 3.82 & $\begin{array}{l}\mathrm{HCO}_{3}-\mathrm{Mg}- \\
\mathrm{Ca}\end{array}$ \\
\hline $\begin{array}{l}\text { N: } 50^{\circ} 9^{\prime} 51^{\prime \prime} \\
\text { E: } \\
19^{\circ} 27^{\prime} 48^{\prime \prime}\end{array}$ & Limestone & 4.1 & 1.9 & 1 & 0.1 & 0.9 & 1.85 & 3.6 & $\mathrm{Ca}\left(\mathrm{HCO}_{3}\right)_{2}$ \\
\hline $\begin{array}{c}\text { N: } 50^{\circ} 17^{\prime} 51^{\prime \prime} \\
\text { E: } 17^{\circ} 8^{\prime} 1^{\prime \prime}\end{array}$ & Granite & 0.56 & 0.16 & 0.31 & 0.04 & 0.17 & 0.17 & 1 & $\mathrm{HCO}_{3}-\mathrm{Ca}$ \\
\hline $\begin{array}{l}\text { N: } 50^{\circ} 17^{\prime} 23^{\prime \prime} \\
\text { E: } \\
17^{\circ} 7^{\prime} 18^{\prime \prime}\end{array}$ & Granite & 1 & 0.2 & 0.16 & 0.12 & 0.065 & 0.067 & 1.36 & $\mathrm{HCO}_{3}-\mathrm{Ca}$ \\
\hline $\begin{array}{l}\text { N: } 50^{\circ} 21^{\prime} 30^{\prime \prime} \\
\text { E: } \\
17^{\circ} 10^{\prime} 55^{\prime \prime}\end{array}$ & Granite & 1.43 & 0.25 & 0.41 & 0.1 & 0.16 & 0.017 & 1.82 & $\mathrm{HCO}_{3}-\mathrm{Ca}$ \\
\hline $\begin{array}{l}\text { N: } 50^{\circ} 21^{\prime} 35^{\prime \prime} \\
\text { E: } \\
17^{\circ} 11^{\prime} 28^{\prime \prime}\end{array}$ & Kaolin & 0.3 & 0.11 & 0.03 & 0.1 & 0.07 & 0.13 & 0.41 & $\mathrm{HCO}_{3}-\mathrm{Ca}$ \\
\hline
\end{tabular}


Table 1 (continued)

\begin{tabular}{|c|c|c|c|c|c|c|c|c|c|}
\hline Location & $\begin{array}{l}\text { Extracted } \\
\text { material }\end{array}$ & $\begin{array}{l}\mathrm{Ca}^{2+} \\
{[\mathrm{meq} / \mathrm{L}]}\end{array}$ & $\begin{array}{l}\mathrm{Mg}^{2+} \\
{[\mathrm{meq} / \mathrm{L}]}\end{array}$ & $\begin{array}{l}\mathrm{Na}^{+} \\
{[\mathrm{meq} / \mathrm{L}]}\end{array}$ & $\mathrm{K}^{+}[\mathrm{meq} / \mathrm{L}]$ & $\mathrm{Cl}^{-}[\mathrm{meq} / \mathrm{L}]$ & $\begin{array}{l}\mathrm{SO}_{4}^{2-} \\
{[\mathrm{meq} / \mathrm{L}]}\end{array}$ & $\begin{array}{l}\mathrm{HCO}_{3}^{-} \\
{[\mathrm{meq} / \mathrm{L}]}\end{array}$ & $\begin{array}{l}\text { Hydrochemi- } \\
\text { cal type }\end{array}$ \\
\hline $\begin{array}{l}\mathrm{N}: 50^{\circ} 18^{\prime} 11^{\prime \prime} \\
\mathrm{E}: \\
17^{\circ} 6^{\prime} 18^{\prime \prime}\end{array}$ & Granite & 1.7 & 0.26 & 0.29 & 0.07 & 0.175 & 0.26 & 1.66 & $\mathrm{HCO}_{3}-\mathrm{Ca}$ \\
\hline $\begin{array}{c}\text { N: } 50^{\circ} 19^{\prime} 57^{\prime \prime} \\
\text { E: } 17^{\circ} 5^{\prime} 1^{\prime \prime}\end{array}$ & Granite & 1.85 & 0.6 & 0.18 & 0.2 & 0.26 & 0.27 & 2.15 & $\mathrm{HCO}_{3}-\mathrm{Ca}$ \\
\hline $\begin{array}{l}\text { N: } 50^{\circ} 18^{\prime} 2^{\prime \prime} \\
\text { E: } \\
17^{\circ} 6^{\prime} 45^{\prime \prime}\end{array}$ & Granite & 1.05 & 0.18 & 2.5 & 2.88 & 1.9 & 0.08 & 4.95 & $\mathrm{HCO}_{3}-\mathrm{K}-\mathrm{Na}^{\mathrm{a}}$ \\
\hline $\begin{array}{l}\mathrm{N}: 50^{\circ} 14^{\prime} 25^{\prime \prime} \\
\mathrm{E}: \\
19^{\circ} 1^{\prime} 16^{\prime \prime}\end{array}$ & Clay & 2.8 & 2.1 & 0.6 & 0.2 & 0.2 & 1.1 & 2.7 & $\mathrm{Ca}\left(\mathrm{HCO}_{3}\right)_{2}$ \\
\hline $\begin{array}{l}\mathrm{N}: 50^{\circ} 39^{\prime} 32^{\prime \prime} \\
\mathrm{E}: \\
18^{\circ} 17^{\prime} 59^{\prime \prime}\end{array}$ & Gravel & 0.6 & 0.1 & 0.07 & 0.02 & 0.04 & 0.15 & 0.45 & $\mathrm{HCO}_{3}-\mathrm{Ca}$ \\
\hline $\begin{array}{l}\mathrm{N}: 50^{\circ} 39^{\prime} 28^{\prime \prime} \\
\mathrm{E}: \\
18^{\circ} 17^{\prime} 53^{\prime \prime}\end{array}$ & Gravel & 0.6 & 0.1 & 0.09 & 0.05 & 0.09 & 0.15 & 0.5 & $\mathrm{HCO}_{3}-\mathrm{Ca}$ \\
\hline $\begin{array}{c}\text { N: } 50^{\circ} 15^{\prime} 55^{\prime \prime} \\
\text { E: } 19^{\circ} 7^{\prime} 7^{\prime \prime}\end{array}$ & Sand & 2.4 & 2.1 & 1.08 & 0.16 & 2.5 & 0.43 & 2.85 & $\mathrm{HCO}_{3}-\mathrm{Ca}$ \\
\hline $\begin{array}{l}\text { N: } 50^{\circ} 00^{\prime} 6^{\prime \prime} \\
\text { E: } \\
19^{\circ} 12^{\prime} 4^{\prime \prime}\end{array}$ & Gravel & 1.49 & 0.46 & 0.51 & 0.08 & 0.42 & 0.62 & 1.5 & $\mathrm{HCO}_{3}-\mathrm{Ca}$ \\
\hline $\begin{array}{l}\mathrm{N}: 50^{\circ} 00^{\prime} 35^{\prime \prime} \\
\mathrm{E}: \\
19^{\circ} 26^{\prime} 55^{\prime \prime}\end{array}$ & Gravel & 2.3 & 0.63 & 0.43 & 0.05 & 0.45 & 1.7 & 1.3 & $\begin{array}{c}\mathrm{Ca}-\mathrm{SO}_{4}- \\
\mathrm{HCO}_{3}\end{array}$ \\
\hline $\begin{array}{l}\text { N: } 50^{\circ} 00^{\prime} 47^{\prime \prime} \\
\text { E: } \\
19^{\circ} 27^{\prime} 12^{\prime \prime}\end{array}$ & Gravel & 2 & 0.65 & 0.43 & 0.05 & 0.53 & 1.3 & 1.3 & $\begin{array}{l}\mathrm{Ca}-\mathrm{HCO}_{3}- \\
\mathrm{SO}_{4}\end{array}$ \\
\hline $\begin{array}{l}\text { N: } 50^{\circ} 39^{\prime} 30^{\prime \prime} \\
\text { E: } \\
18^{\circ} 17^{\prime} 55^{\prime \prime}\end{array}$ & Gravel & 0.6 & 0.1 & 0.09 & 0.05 & 0.09 & 0.15 & 0.5 & $\mathrm{HCO}_{3}-\mathrm{Ca}$ \\
\hline
\end{tabular}

${ }^{a}$ Reservoirs with industrial waste deposition in the coastal zone

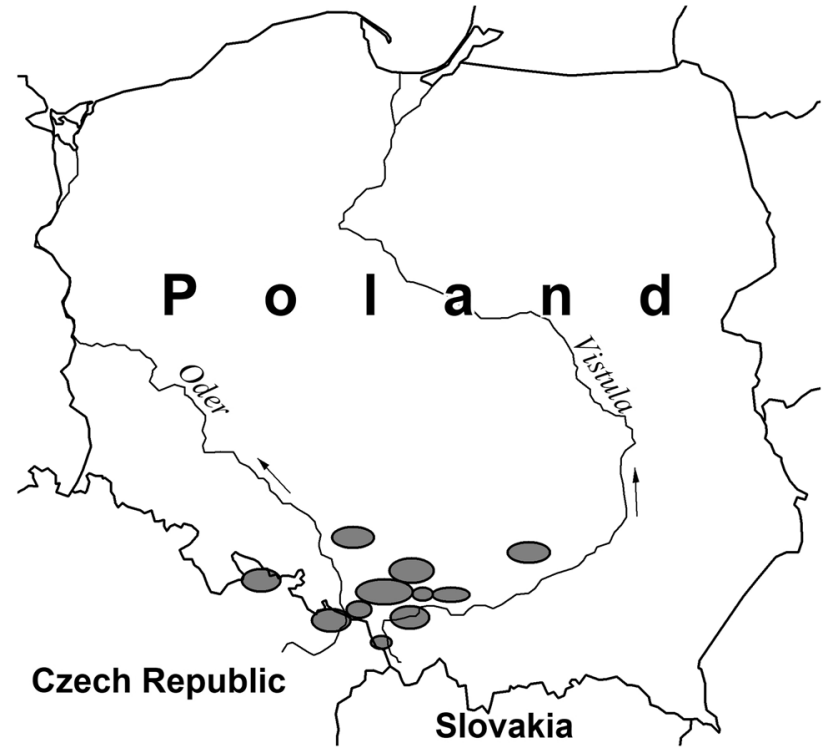

Fig. 2 Location of the study area in the permanent stratification of the water-meromixing (Molenda 2014).

Pit lakes 3-6 contained double-ionic sulphate-calcium water $\left(\mathrm{SO}_{4}{ }^{2-}-\mathrm{Ca}^{2+}\right.$, Table 1$)$. These pit lakes are located in post-exploitation gypsum excavations. Gypsum is susceptible to dissolution, which produces calcium $\mathrm{Ca}^{2+}$ and sulphate $\mathrm{SO}_{4}{ }^{2-}$ ions in such large quantities that they determined the chemical composition of the water. Therefore, in the case of these pit lakes, the chemical composition of the water was conditioned by a geological factor.

The same sulphate-calcium $\left(\mathrm{SO}_{4}{ }^{2-}-\mathrm{Ca}^{2+}\right)$ type of water was also found in pit lakes 7-11. A characteristic feature of these pit lakes, however, was the complete lack of a bicarbonate ion $\left(\mathrm{HCO}_{3}{ }^{-}\right.$, Table 1$)$. In the case of pit lakes 9, 10, and 11 , the lack of a bicarbonate ion was conditioned by the mineral composition of the rocks that had been exploited in the excavation. In the case of pit lakes 9 and 10, the extracted material was lignite, while quartzite sandstones were extracted at the site of pit lake 11 . These rocks contain 
Table 2 Climatic characteristics of the study area representative for reservoirs located in Poland

\begin{tabular}{|c|c|c|c|c|c|c|c|c|c|c|c|c|c|}
\hline Months & Jan & Feb & Mar & Apr & May & Jun & Jul & Aug & Sep & Oct & Nov & Dec & Year \\
\hline Mean air temperature $\left({ }^{\circ} \mathrm{C}\right)$ & -3.3 & -2.1 & 1.9 & 7.6 & 13.0 & 16.5 & 18.0 & 17.3 & 13.6 & 8.1 & 3.4 & -0.6 & 7.8 \\
\hline Mean precipitation $(\mathrm{mm})$ & 49 & 46 & 41 & 37 & 40 & 49 & 85 & 89 & 105 & 88 & 53 & 50 & 731 \\
\hline Mean speed of wind $(\mathrm{m} / \mathrm{s})$ & 3.0 & 2.5 & 3.0 & 4.0 & 3.5 & 3.5 & 3.0 & 2.5 & 3.0 & 4.0 & 4.0 & 3.0 & 3.25 \\
\hline
\end{tabular}

Table 3 Climatic characteristics of the study area representative for reservoirs located in the Czech Republic

\begin{tabular}{|c|c|c|c|c|c|c|c|c|c|c|c|c|c|}
\hline Months & Jan & Feb & Mar & Apr & May & Jun & Jul & Aug & Sep & Oct & Nov & Dec & Year \\
\hline Mean air temperature $\left({ }^{\circ} \mathrm{C}\right)$ & 0.1 & -5.5 & 5.6 & 10.1 & 15.6 & 17.9 & 20.6 & 19.7 & 14.9 & 9.2 & 6.5 & -1.0 & 9.4 \\
\hline Mean precipitation (mm) & 25.3 & 31.8 & 45.2 & 50.5 & 76.1 & 102.8 & 114.2 & 82.3 & 69.7 & 38.6 & 42.2 & 33.6 & 712.3 \\
\hline Mean speed of wind $(\mathrm{m} / \mathrm{s})$ & 2.4 & 2.3 & 2.4 & 2.6 & 2.4 & 2.1 & 2.1 & 2.1 & 2.4 & 2.2 & 2.3 & 2.3 & 2.3 \\
\hline
\end{tabular}

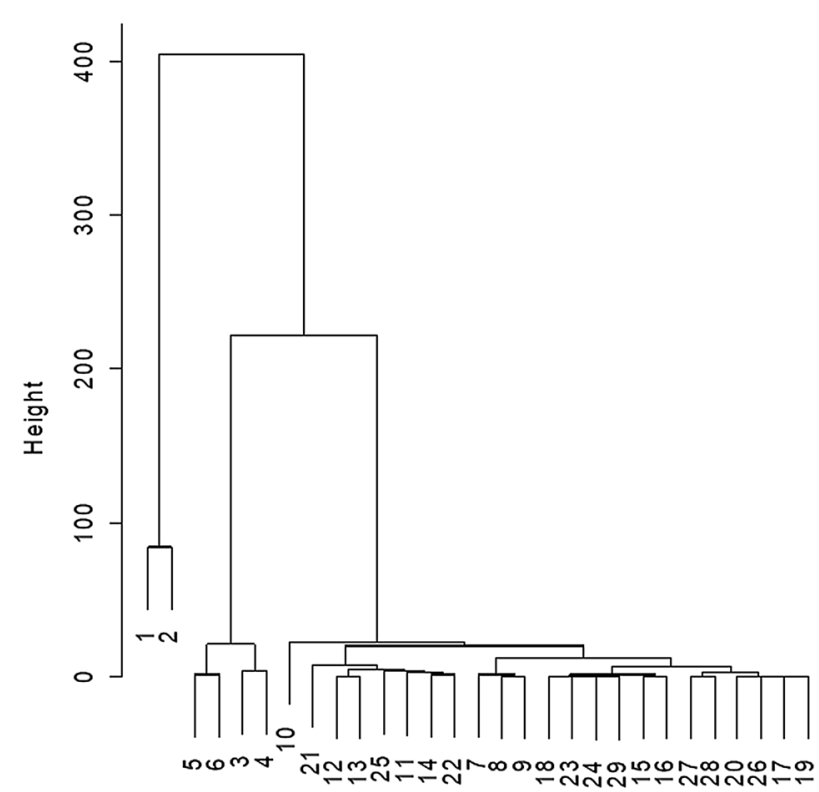

Fig. 3 The multidimensional clustering of reservoirs due the chemical composition of their waters

iron sulphides in their composition, mainly pyrite $\left(\mathrm{FeS}_{2}\right)$ (Matl 1991; Migaszewski and Gałuszka 2007). The weathering of these minerals leads to the acidification of the pit lake waters $(\mathrm{pH}<4.0)$, and the disappearance of bicarbonate ions. This effect of the weathering of sulphide minerals has also been documented at other excavations of lignite (Schultze et al. 2010; Solski and Jędrczak 1990) and polymetallic ores (Sánchez-España et al. 2013; Shevenell et al. 1999).

Pit lake 8 also had no bicarbonate ions (Table 1). The basin of this pit lake was developed in dolomite rocks. Therefore, it should have been a bicarbonate-magnesium-calcium water type $\left(\mathrm{HCO}_{3}{ }^{-}-\mathrm{Mg}^{2+}-\mathrm{Ca}^{2+}\right)$ like the other pit lakes located in disused dolomite pits (Table 1). However, it is a sulphate-calcium-magnesium $\left(\mathrm{SO}_{4}{ }^{2-}-\mathrm{Ca}^{2+}-\mathrm{Mg}^{2+}\right)$ water

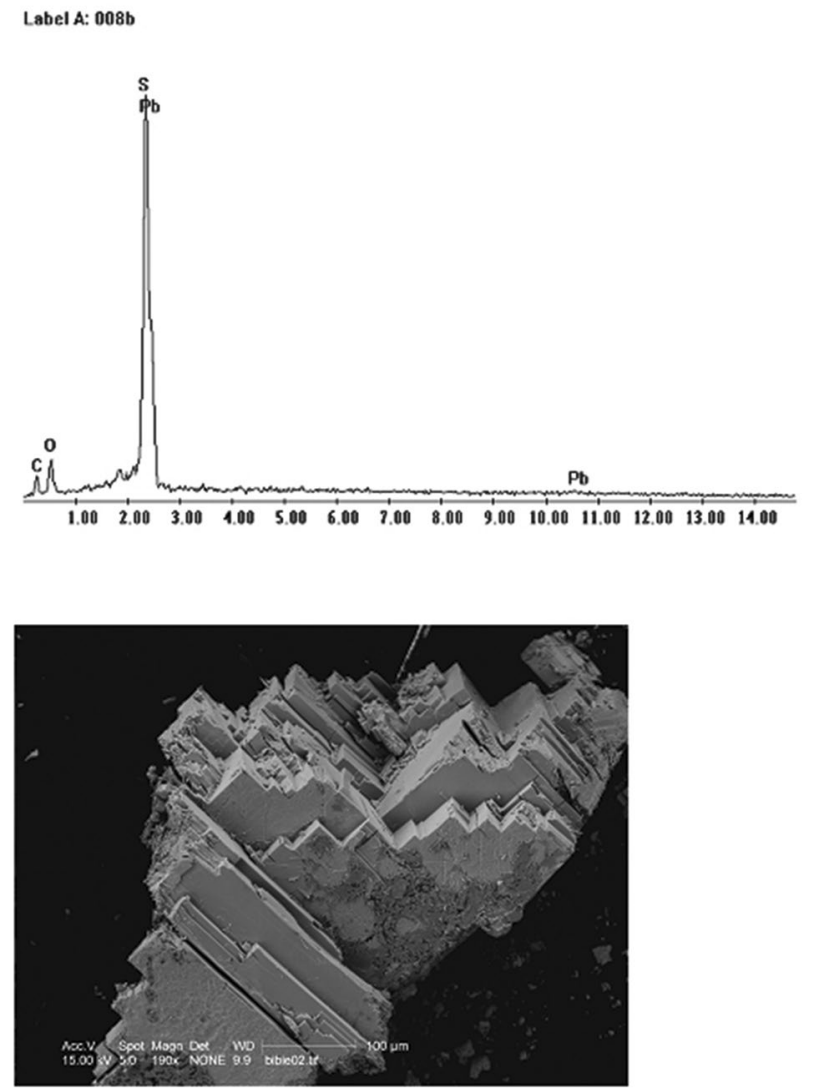

Fig. 4 The elemental spectrum and a photo of the $\mathrm{PbS}$ molecule from the heap of Bibiela, magn. 190x

type, due to the inflow of acidic leachate from an industrial waste landfill located in the direct catchment of the pit lake. The waste in this landfill contains significant amounts of metal sulphides, mainly pyrite $\left(\mathrm{FeS}_{2}\right)$ and galena $(\mathrm{PbS})$ (Fig. 4). Because of the weathering process of these minerals, acidic leaks with $\mathrm{pH}<2$ reach the pit lake (Fig. 5), which leads to the transformation of the ionic composition 


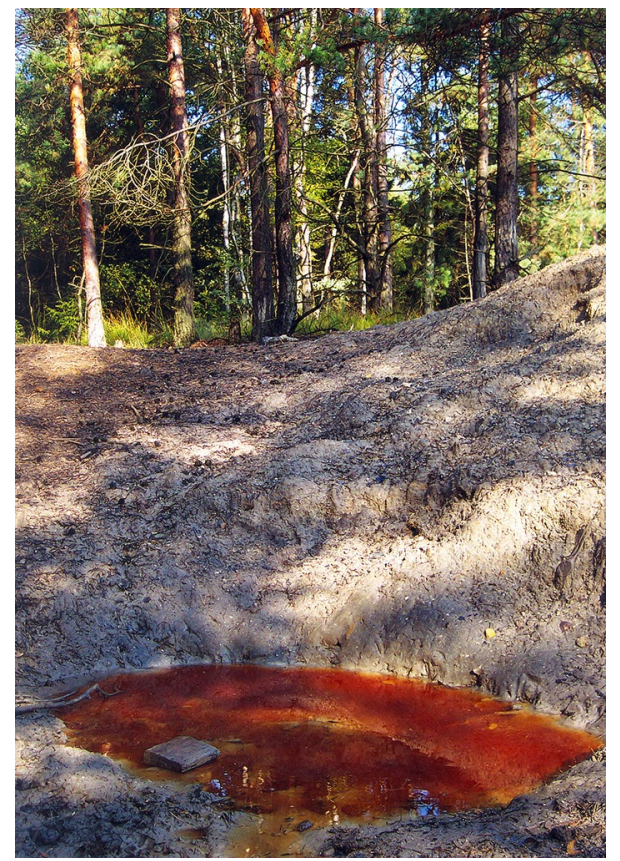

Fig. 5 Acidic leachate $(\mathrm{pH}<2$, the average: EC-5.9 $\mathrm{mS} / \mathrm{cm}$, $\left.\mathrm{SO}_{4}{ }^{2-}-4800 \mathrm{mg} / \mathrm{dm}\right)$

of the waters. The formation of acid leachates was also found in other landfills containing metal sulphides (Lin 1997). A similar situation occurred in the case of pit lake 7. Its basin is a disused sandpit, and thus we dealt with an unusual type of water for this type of sediment $\left(\mathrm{SO}_{4}{ }^{2-}-\mathrm{Ca}^{2+}\right)$. In addition, in this case, the source of the water acidification was an inflow of leachate from a hard coal mining landfill. These wastes contained pyrite and hydrogen jarosite-the source of acidic substances (Table 4).

A distinctive chemical composition was also found in the pit lakes that formed in dolomite excavations 13 and 14 . The water of these pit lakes is of a tri-ionic bicarbonate-magnesium-calcium type $\left(\mathrm{HCO}_{3}{ }^{-}-\mathrm{Mg}^{2+} \mathrm{Ca}^{2+}\right)$. Periodically, they can turn into bicarbonate-magnesium water $\left(\mathrm{HCO}_{3}{ }^{-}-\mathrm{Mg}^{2+}\right)$. However, the meq/L concentration of the magnesium is always higher than that of the calcium, due to the nature of the dolomites.

A characteristic, double-ion calcium-bicarbonate $\left(\mathrm{Ca}\left(\mathrm{HCO}_{3}\right)_{2}\right)$ type of water was recorded in the pit lakes located at limestone excavations 12 and 15 . This is a typical

Table 4 Composition [\%] of mining waste

\begin{tabular}{lr}
\hline Phase & {$[\%]$} \\
\hline Calcite & 89.1 \\
Dolomite & 9.5 \\
Gypsum & 1.1 \\
Quartz & 0.1 \\
Magnesite & 0.2 \\
\hline
\end{tabular}

hydrochemical composition of waters in limestone areas (Miche et al. 2018).

The pit lakes located in granite and granodiorite quarries (16-22) were the double-ion bicarbonate-calcium $\left(\mathrm{HCO}_{3}{ }^{-}-\mathrm{Ca}^{2+}\right)$ water type. Only one of the lakes (22) differed; it was a bicarbonate-potassium-sodium $\left(\mathrm{HCO}_{3}{ }^{-}-\mathrm{K}^{+}-\mathrm{Na}^{+}\right)$type, due to the deposition of industrial waste in the coastal zone of the pit lake. The mineral composition of the waste deposited in the landfill is shown in Table 5. The waste leaching processes in the landfill transformed the ionic composition of the pit lake water. The impact of industrial waste landfills on the ionic composition of water was also found in the "Górka" pit lakes, located in Trzebinia (Czop et al. 2011).

The bicarbonate-calcium hydrochemical type of water is also characteristic of the other pit lakes located in former gravel excavations. It is the most commonly occurring type of water, and has been recorded in many pit lakes (Meybeck and Helmer 1989; Meybeck 2005; Wetzel 2000).

\section{Summary and Conclusions}

The chemical composition of the water of pit lakes depends on several factors, the most important of which is geogenic, i.e. the type of rocks in which the pit lake basin is located. This is particularly noticeable in excavations developed by the mining of karst rock (gypsums, dolomites, and limestones). The dissolution of these rocks completely determines the hydrochemical type of water retained in the lake. An admixture of sulphide minerals in the disturbed strata rocks also affected the hydrochemical type of mine waters. This applies mainly to the lignite excavations in this study, which often contained a significant admixture of pyrite $\left(\mathrm{FeS}_{2}\right)$.

In the case of pit lakes embedded in poorly soluble rocks (granite, granodiorite), the water has a very low ion concentration. Its chemical composition is primarily determined by rainwater and is of a bicarbonate-calcium type, which is the most common one in nature. The low mineralisation of both surface and underground water is characteristic of areas

Table 5 Composition [\%] of waste

\begin{tabular}{lc}
\hline Phase & {$[\%]$} \\
\hline Minerals clay & 37.5 \\
Quartz & 27.5 \\
Feldspar soda and potassium & 12 \\
Hydronium jarosite & 5 \\
Potassium halite & 2 \\
Pyrite & 1 \\
Amorphous substance (carbonate) & 15 \\
\hline
\end{tabular}


that are built of crystalline rocks. In addition to the natural (geogenic) factors, the inflow of leachates from industrial waste dumps can have a significant impact on the chemical composition of waters. Very often, old excavations become places to dispose of various types of waste (Czop et al. 2011). The significant impact of industrial waste landfills was demonstrated by pit lake 22 , in which an atypical threeionic $\left(\mathrm{HCO}_{3}{ }^{-}-\mathrm{K}^{+}-\mathrm{Na}^{+}\right)$type of water was found.

The chemical composition of water (resulting from geogenic conditions) can also be completely transformed by the discharge of mine waters from deep mines. Pit lakes 1 and 2 , into which brine from coal mines was discharged, are good examples.

The concentrations of ions in the water of central Europe's pit lakes situated in the excavations of the same rock types may show slight differences, which are determined by the amount of rainwater inflow. However, they always represent the same hydrochemical type, unless influenced by secondary anthropogenic factors.

Open Access This article is licensed under a Creative Commons Attribution 4.0 International License, which permits use, sharing, adaptation, distribution and reproduction in any medium or format, as long as you give appropriate credit to the original author(s) and the source, provide a link to the Creative Commons licence, and indicate if changes were made. The images or other third party material in this article are included in the article's Creative Commons licence, unless indicated otherwise in a credit line to the material. If material is not included in the article's Creative Commons licence and your intended use is not permitted by statutory regulation or exceeds the permitted use, you will need to obtain permission directly from the copyright holder. To view a copy of this licence, visit http://creativecommons.org/licenses/by/4.0/.

\section{References}

Boehrer B, von Rohden C, Schultze M (2017) Physical features of meromictic lakes: stratification and circulation. In: Gulati RD, Zadereev ES, Degermendzhi AG (eds) Ecology of meromictic lakes ecological studies, vol 228. Springer, Berlin, pp 15-34

Castendyk DN, Eary LE, Balistrieri LS (2015a) Modeling and management of pit lake waterchemistry 1: theory. Appl Geochem 57:267-288

Castendyk DN, Balistrieri LS, Gammons C, Tucci N (2015b) Modeling and management of pit lake water chemistry 2: case studies. Appl Geochem 57:289-307

Czop M, Motyka J, Sracek O, Szuwarzyński M (2011) Geochemistry of the Hyperalkaline Gorka pit lake in the Chrzanow region. Southern Poland. Water Air Soil Pollut 214:423-434

Eary LE (1999) Geochemical and equilibrium trends in mine pit lakes. Appl Geochem 14:963-987

Hammer UT (1986) Saline lake ecosystems of the world. Dr W. Junk Publishers, Dordrecht

Hutchinson GE (1975) A treatise on limnology: chemistry of lakes. Vol I, Part 1: geography and physics of lakes. Wiley, Hoboken

Imberger J, Patterson JC (1990) Physical limnology. In: Wu T (ed) Advances in applied mechanics, vol 27. Academic Press, Boston, pp 303-475
Jankowski AT (1995) From research on anthropogenic water reservoirs in the Upper Silesian area. Selected geographical issues. WNoZ UŚ, Sosnowiec (in Polish)

Jones D, Laurencont T, Unger C (2003) Towards achieving sustainable water management for an acidic open cut pit at Mount Morgan, Queensland. In: Proceedings on 6th ICARD, AUSIMM, Cairns, QLD, Australia, pp 513-519

Lin Z (1997) Mineralogical and chemical characterization of wastes from the sulfuric acid industry in Falun, Sweden. Environ Geol 30(3-4):152-162

Malata M, Motyka J, d'Obyrn K, Postawa A (2018) Chemical composition of water in a sunken plaster cast "Gacki" (Niecka Niedziańska). Opencast mining, ISSN 0043-2075. 59 nr 2, pp 43-49(in Polish)

Matl K (1991) Geological structure of small surface brown coal deposits. Miner Resour Econ 7(2):267-290 (in Polish)

Meybeck M (2005) Global occurrence of major elements in rivers. In: Drever JI, Holland HD, Turekian KK (eds) Treatise on geochemistry, Vol 5, surface and ground water, weathering, and soils. Elsevier, Amsterdam, pp 207-223

Meybeck M, Helmer R (1989) The quality of rivers: from pristine stage to global pollution. Palaeogeogr Palaeoclimatol 75(4):283-309

Miche H, Saracco G, Mayer A, Qarqori K, Rouai M, Dekayir A, Chalikakis K, Emblanch C (2018) Hydrochemical constraints between the karst Middle-Atlas-Causses and the Sais basin (Morocco): implication of groundwater circulations. Hydrogeol J 26(1):7187. https://doi.org/10.1007/s10040-017-1675-0

Migaszewski ZM, Gałuszka A (2007) Fundamentals of Environmental Geochemistry. Science and Technology Publishers, Warsaw (in Polish)

Molenda T (2007) Impact of the catchment on the chemical properties of anthropogenic reservoir waters (on the example of excavation reservoirs). Condition and Anthropogenic Changes in Water Quality in Poland. Univ Lodz Hydrol Comm Pol Geogr Soc 5:157-165 (in Polish)

Molenda T (2014) Impact of saline mine water: development of a meromictic reservoir in Poland. Mine Water Environ 33:327-334. https ://doi.org/10.1007/s10230-014-0262-z

Molenda T (2015) Conditions for development of anthropogenic meromictic reservoirs in the workings of crystalline rocks (based on the examples of the quarries of the Zulowska pahorkatina, NE Czech Republic). Environ Earth Sci 74:2259-2271. https://doi. org/10.1007/s12665-015-4217-x

Molenda T (2018) Impact of a saline mine water discharge on the development of a meromictic pond, the Rontok Wielki Reservoir, Poland. Mine Water Environ 37(4):807-814. https://doi. org/10.1007/s10230-018-0544-y

Molenda T, Chmura D (2011) Seasonal changes in selected physicochemical parameters of saline water bodies. Ecol Chem Eng A 18(2):225-233

Pazdro Z, Kozerski B (1990) General hydrogeology. Geological Publishing, Warsaw (in Polish)

R Development Core Team (2009) R. A language and environment for statistical computing. R Foundation for Statistical Computing, Vienna

Rahaingomanana N (1998) Water chemistry characteristics in small reservoirs of semiarid Tunisia. In: Proceedings on international seminar on rain water harvesting and management of small reservoirs in arid and semiarid areas, an expert meeting within the EU-INCO collaboration HYDROMED, pp 95-106

Rzętała M (2008) The functioning of water reservoirs and the course of limnic processes under conditions diverse anthropopression on the example of the region of Upper Silesia. University of Silesia Publishing, Katowice (in Polish)

Sánchez-España J, Diez M, Santofimia E (2013) Mine pit lakes of the Iberian Pyrite Belt: some basic limnological, hydrogeochemical 
and microbiological considerations. In: Geller W, Schultze M, Kleinmann B, Wolkersdorfen C (eds) Acidic pit lakes. Springer, Heidelberg, pp 315-342

Sánchez-España J, Boehrer B, Yusta I (2014) Extreme carbon dioxide concentrations in acidic pit lakes provoked by water/rock interaction. Environ Sci Technol 48(8):4273-4281. https://doi. org/10.1021/es5006797

Schultze M, Pokrandt K-H, Hille W (2010) Pit lakes of the central German lignite mining district: creation, morphometry and water quality aspects. Limnologica 40:148-155

Schultze M, Hemm M, Geller W, Benthaus F-C (2013) Pit lakes in Germany: hydrography, water chemistry, and management. In: Geller W, Schultze M, Kleinmann R, Wolkersdorfer C (eds) Acidic pit lakes. Springer, Heidelberg, pp 265-291

Schultze M, Boehrer B, Wendt-Potthoff K, Katsev S, Brown ET (2017a) Chemical setting and biogeochemical reactions in meromictic lakes. In: Gulati RD, Zadereev ES, Degermendzhi AG (eds) Ecology of meromictic lakes, ecological studies. Springer, Berlin, pp 35-59

Schultze M, Boehrer B, Wendt-Potthoff K, Sánchez-España J, Castendyk D (2017b) Meromictic pit lakes: case studies from Spain, Germany and Canada and general aspects of management and modelling. In: Gulati RD, Zadereev ES, Degermendzhi AG (eds) Ecology of meromictic lakes, ecological studies, vol 228. Springer, Berlin, pp 235-275

Shevenell L, Cannors KA, Henry CD (1999) Controls on pit lake water quality at sixteen open-pit mines in Nevada. Appl Geochem 14:669-687

Solski A, Jędrczak A (1990) Ionic composition of waters of the ,anthropogenic lake district”. Pol Arch Hydrob 37(3):361-382

Wetzel RG (2000) Limnology, 2nd edn. Saunders College Publishing, Philadelphia 